\title{
The identification of bacteria associated with periodontal disease and dental caries by enzymatic methods
}

Walter J. Loesche

University of Michigan School of Dentistry

Ann Arbor, Michigan 48109

\author{
Loesche WJ: The identification of bacteria associated with periodontal disease and \\ dental caries by enzymatic methods. \\ Oral Microbiol Immunol 1986; 1: 65-70.
}

This brief review describes the potential usefulness of enzymatic reagents for the diagnosis of dental caries and periodontal disease. The cultural tests for salivary $S$. mutans levels should soon become commercially available in the U.S. and their success may preclude the immediate development of enzymatic diagnostic reagents for this group of organisms. However, in regards to periodontal disease, these enzyme reagents offer great promise, particularly those which measure the trypsin-like activity of plaque. The BANA hydrolytic activity of plaque, while not due exclusively to the spirochetes, nevertheless seems to reflect the spirochetal load of the plaque. Of even greater interest is the possibility that this and other enzymes can also be measured in the saliva. This would lend itself to routine screening for these enzymes in the saliva.

\section{Introduction}

The cost efficiency of any antibacterial treatment in dentistry, be it preventive or therapeutic, increases to the extent that it can be focused upon those populations or individuals who are at actual risk of decay or periodontal disease. In the past, and in many places in the present, all children were considered at risk of decay, and all adults were considered at risk of periodontal disease, so that the need to diagnose an infection was moot. Now with the demonstration of Streptococcus mutans and lactobacilli as the prime etiologic agents in human dental decay (15), and spirochetes (13, $17,19), B$. gingivalis $(19,26), H$. actinomycetemcomitans $(26,36)$ and others $(21,31,33)$ as prime etiologic agents in periodontal disease, it is possible to identify those individuals with an odontopathic infection, and treat them either prospectively so as to prevent dental diseases, or therapeutically so as to cure these infections (14).

Approximately 200 to 300 bacterial species colonize human dental plaques
$(22,28)$, but as noted above only a finite number have been associated with either dental caries or periodontal disease. The diagnostic problem then is the identification and quantification of the odontopathogens against the background of a very complex and highly variable plaque flora. How can one reliably and routinely document that $H$. actinomycetemcomitans or $B$. gingivalis is present in a single plaque sample when it comprises less than $0.1 \%$ of the cultivable flora? What is the significance of $10 \%$ spirochetes vs $25 \%$ spirochetes, or $5 \%$ S. mutans vs $15 \%$ S. mutans?

Cultural studies have been essential for the implication of certain species as odontopathogens, but even with the very best transport and selective media, cultural methods may not be reliable or inexpensive enough to become the routine means by which odontopathic infections are diagnosed. This is certainly the current situation with periodontal infections, but may be otherwise with the culturing of saliva for $S$. mutans and lactobacilli $(9,15)$.

Microscopic examination of plaque for the presence and levels of motile organisms and spirochetes is a reliable and simple procedure (13), that has been widely publicized (7) but apparently minimally accepted by the clinician (35). Additional information may be obtained if highly specific fluorescent antibodies are used in conjunction with microscopic procedures $(27,38)$, but this requires a battery of antibodies to recognize each serotype of each putative odontopathogen, and assumes that the sought after antigen(s) in the plaque is (are) biologically exposed to the antibody. An even more specific and sensitive diagnostic agent would be the use of a DNA probe for each odontopathogen. This would require that the DNA of odontopathic species can be made accessible in a stable form; i.e. is not hydrolyzed by the DNAses found in plaque (3).

An alternate diagnostic possibility is the monitoring of the presence and levels of certain bacterial or host enzymes directly in the plaque (30), gingival crevicular fluid (3) or in the saliva (23). This possibility has evolved from 
the current usage of enzyme diagnostic reagents for the rapid indentification of pure bacterial colonies that have been isolated from plaque $(6,11,12,25,32)$. In particular the ability of the putative periodontal pathogens B. gingivalis (11, 25), $T$. denticola (11) and $B$. forsythus (32) to hydrolyze various synthetic substrates of trypsin led to studies which suggest that this trypsin-like enzyme(s) may be a diagnostic marker for both clinical disease and the magnitude of the spirochetal infection (17a).

In this review the use of enzymebased markers as a means of diagnosing either a cariogenic $S$. mutans infection or a proteolytic anaerobic infection presumably due to spirochetes and/or bacteroides will be described.

\section{Lessons learned from S. mutans}

S. mutans was initially thought to be a single species but extensive serological (1) and genetic (4) studies led to the recognition of 9 serotypes and at least 6 genetically distinct species $(4,15)$. This complexity along with the observation that most if not all individuals harbored one of the mutans streptococci frustrated the development of highly specific fluorescent antibody reagents. As a result a greater reliance was placed upon cultural studies for the obtaining of reliable quantitative data. In this process the relationship between salivary and plaque levels of $S$. mutans was established $(29,34)$, and in turn the relationship between salivary levels of $S$. mutans and the degree of present and prospective caries activity was empirically determined $(8,9,39,40)$.

This serological and genetic complexity led Shklair and Keene (24) to develop a phenotype characterization of the various mutans streptococci that resulted in a simple biotyping scheme (Table 1), that relies upon characteristics that reflect enzyme activity. Thus the mutans streptococci ferment mannitol and form adherent glucans via a variety of glucosyltransferases (GTF) (2).

Table 1. Biochemical scheme used to speciate the mutans streptococcia

\begin{tabular}{lccccc}
\hline Species & Serotypes & Raffinose & Melibiose & $\begin{array}{c}\mathrm{NH}_{3} \text { from } \\
\text { Arginine }\end{array}$ & $\begin{array}{c}\text { Resistance to } \\
\text { Bacitracin }\end{array}$ \\
\hline S. mutans & c, e, f & + & + & - & + \\
S. sobrinus & d, g, h & - & - & - & + \\
S. rattus & b & + & + & + & + \\
S. cricetus & a & + & + & - & - \\
\hline
\end{tabular}

a) All strains ferment mannitol and form extracellular glucans adapted from Shklair and Keene (24). the utilization of raffinose, melibose, the liberation of $\mathrm{NH}_{3}$ from arginine and in their resistance to bacitracin, thereby forming 4 distinct groups which corresponded to the genetic groups. Note that only $S$. mutans and $S$. sobrinus are human organisms (15), so that a diagnostic test in most instances need only identify these two species.

Tests that sought to reveal all the mutans streptococci in a dichotomous fashion by virtue of their ability to ferment mannitol were not specific and were unable to distinguish between high and low levels of the mutans streptococci (16). A breakthrough was the description of a selective agar medium (MSB agar) which relied upon $20 \%$ sucrose and $0.2 \mu / \mathrm{ml}$ bacitracin to provide quantitative data on the numbers of the mutans streptococci in plaque and saliva (5). The widespread usage of this MSB medium allowed investigators to determine what salivary levels of mutans streptococci were associated with decay and which levels were assoicated with the caries free condition. Thus, individuals with more than $10^{6}$ mutans streptococci per $\mathrm{ml}$ saliva are highly infected and should be aggressively treated (9). This treatment should be repeated if the mutans streptococci do not drop below $2.5 \times 10^{5} \mathrm{CFU} / \mathrm{ml}(8$, 39).

These empirically determined guidelines have put the delivery of dental care on a scientific basis $(9,15)$, but require that a professionally-staffed bacteriology laboratory perform the actual tests. Efforts have been made to package the MSB medium in a form that allows it to be used in the dental office. One such kit is a modification of the dip-culture initially described for salivary lactobacilli counts (10), whereas another kit is simply a small tube incubated at an angle that takes into account the ability of the mutans streptococci to form adherent polysaccharides (20). The latter test has been shown to reflect salivary mutans streptococci
The various species react uniquely to

.

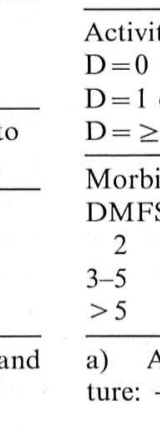$$
\text { 年 }
$$

levels, but no data have apparently been published showing its ability to reflect the caries status of the individual. There are no published data on the dipculture kit. We have compared both kits using the same saliva sample and have related the findings to the caries morbidity (the DMFS score) and activity (the D score) of the subjects (Table 2). Both tests identified individuals with high levels of morbidity and activity, but the dip-culture exhibited the greater specificity as it recognized those mutans treptococci negative and caries negative subjects.

This brief review of diagnostic tests for the mutans streptococci shows how the combination of cultural and enzymatic methodologies has led to the development of a simple, inexpensive and apparently reliable diagnostic tests that can be used in the dental office.

\section{The use of enzyme methodologies in periodontal disease}

The periodontal microbiology is more complex than that associated with dental decay and it is in this area that enzyme technology offers promise in the area of diagnosis. Commercially available enzyme diagnostic kits have been particularly helpful in the identification of pure cultures of plaque isolates. Moreover, as we accumulate information regarding the enzyme profiles of plaque isolates, one or more patterns are emerging that suggest certain enzymes may be characteristic of the periodontopathogens, and it appears that these enzymes can be reliably measured directly in the plaque or saliva. If this can be validated then the possibility exists for direct enzyme readings on the

Table 2. Relationship between salivary $S$. mutans tests and active decay or caries morbidity (DMFS scores)

\begin{tabular}{|c|c|c|c|c|}
\hline & \multicolumn{2}{|c|}{$\begin{array}{c}\text { Adherence } \\
\text { Test }\end{array}$} & \multicolumn{2}{|c|}{ Dip-culture } \\
\hline & $+^{a}$ & - & $+^{a}$ & - \\
\hline \multicolumn{5}{|l|}{ Activity } \\
\hline $\mathrm{D}=0$ & 5 & 3 & 3 & 5 \\
\hline $\mathrm{D}=1$ or 2 & 4 & 3 & 6 & 2 \\
\hline $\mathrm{D}=\geq 3$ & 14 & 2 & 12 & 4 \\
\hline \multicolumn{5}{|l|}{ Morbidity } \\
\hline $\mathrm{DMFS}=0$ & 1 & 1 & 0 & 2 \\
\hline 2 & 1 & 2 & 1 & 2 \\
\hline $3-5$ & 4 & 1 & 3 & 2 \\
\hline$>5$ & 17 & 4 & 17 & 5 \\
\hline
\end{tabular}

$+=$ score $\geq 3$. 
plaque using procedures suitable for the dental office.

\section{A. Enzymatic identification of plaque isolates}

Commercially available enzyme kits such as API ZYM (API System, La Balme les Grottes, Montalieu-Vercieu, France) and An-Ident (Analytab Products, Plainview, N.Y.), have been used by several groups to characterize plaque isolates. These enzyme assays have permitted the rapid and reliable speciation of the black pigmented Bacteroides (BPB) (11). While it had long been known that multiple species exist among these organisms, it has only been in recent years that one of these species, $B$. gingivalis has emerged as a true periodontal pathogen $(19,26)$. Thus, in the diagnosis of a periodontal infection it is appropriate to demonstrate that it is $B$. gingivalis that is present, and if one were to initiate interceptive treatment, then it is imperative to show that $B$. gingivalis is involved. This can be easily done by showing that the isolated BPB possess a trypsin-like activity, as only $B$. ging $i$ valis of the human $\mathrm{BPB}$ gives a positive trypsin-like test (Table 3$)(11,25)$. This identification is confirmed by negative enzyme assays for $\alpha$-glucosidase and $\mathrm{N}$ acetyl- $\beta$-glucosaminidase. In fact, with these 3 enzyme assays the majority of the oral BPB can be adequately speciated (Table 3).

Enzyme assays can be used to distinguish $H$. actinomycetemcomitans from the closely related $H$. aphrophilus and from several Actinobacillus species (Table 4) (25). Of particular interest was the finding that Bacteroides forsythus, a slow growing, anaerobe isolated from sites of active periodontal destruction (31) yielded strong positive reactions for $\alpha$-fucosidase, $N$-acetyl- $\beta$-glucosami-

Table 3. Distinguishing enzyme patterns of black pigmented bacteroides ${ }^{\text {a) }}$

\begin{tabular}{|c|c|c|c|}
\hline Species & Trypsin-like & $a$-glucosidase & $\begin{array}{c}\text { N-acetyl- } \beta \text { - } \\
\text { glucosaminidase }\end{array}$ \\
\hline B. gingivalis & + & - & - \\
\hline B. endodontalis & - & - & - \\
\hline B. intermedius & - & + & - \\
\hline B. melaninogenicus & - & + & + \\
\hline B. asaccharolyticus & - & - & \pm \\
\hline non human strains ${ }^{\text {b) }}$ & \pm & - & \pm \\
\hline
\end{tabular}

a) Data taken from Slots, 1981; Laughon et al. 1982.

b) B. levii, B. macacae, catalase + beagle dog isolates.

Table 4. Distinguishing enzyme patterns of Actinobacillus and Hemophilus species

\begin{tabular}{lcccc}
\hline Species & $\begin{array}{c}\beta \text {-galacto- } \\
\text { sidase }\end{array}$ & $\begin{array}{c}\alpha \text {-gluco- } \\
\text { sidase }\end{array}$ & $\begin{array}{c}\beta \text {-glucuro- } \\
\text { nidase }\end{array}$ & $\begin{array}{c}\text { esterase- } \\
\text { lipase }\end{array}$ \\
\hline H. actinomycetemcomitans & - & - & - & \pm \\
H. aphrophilus & + & + & - & - \\
A. equuli & + & - & - & + \\
A. lignieresii & + & - & - & - \\
A. suis & + & - & + & - \\
A. seminis & - & - & + \\
\hline
\end{tabular}

Adapted from Slots, 1981, J. Clin. Microbiol. 14: 288-294.

Table 5. Enzyme reactions of fastidious oral gram negative species

\begin{tabular}{lccccc}
\hline Species & $\begin{array}{c}\text { Trypsin- } \\
\text { like }\end{array}$ & $\begin{array}{c}a \text {-gluco- } \\
\text { sidase }\end{array}$ & $\begin{array}{c}a \text { and } \beta \\
\text { galactosidase }\end{array}$ & $\begin{array}{c}\text { proline amino } \\
\text { peptidase }\end{array}$ & $\begin{array}{c}\text { esterase } \\
\text { lipase }\end{array}$ \\
\hline B. forsythus & + & + & - & - & - \\
B. gracilis & - & - & - & - & weak \\
B. ureolyticus & - & - & - & - & weak \\
B. buccae & - & + & - & - & - \\
Capnocytophaga sp. & - & + & - & - & weak \\
Wolinella sp. & - & - & - & - & weak \\
Campylobacter concisus & - & - & - & - & - \\
E. corrodens & - & - & + & + & - \\
Selenomonas sputigena & & - & - & -
\end{tabular}

Adapted from Tanner et al. 1985. J Clin. Microbiol. 22: 333-335. nidase, $\alpha$-glucosidase, $\beta$-glucuronidase and $\mathrm{N}$-acetyl glucosaminidase, all reactions which suggest that this fastidious organism uses glycoproteins as energy substrates. By selection of a few enzyme markers this organism could be easily differentiated from several other fastidious gram negative anaerobes as well as other fusiform organisms such as the Capnocytophaga and Fusobacterium species (Table 5) (32).

\section{B. Plaque levels of trypsin-like enzymes} $B$. forsythus also possesses a trypsin-like enzyme, thereby sharing this marker with $B$. gingivalis, the small spirochete T. denticola and an unspeciated Capnocytophaga species (12). This enzyme activity is usually measured as the hydrolysis of the colorless substrate Nbenzyol-DL-arginine-2-naphthylamide (BANA), thereby releasing the chromophore ( $\beta$-napthylamide) which turns a bright orange-red when a drop of fast garnet is added to the solution (11). The BANA activity of various subgingival gram negative species is listed in Table 6.

As the BANA positive species are putative periodontal pathogens, it was of interest to determine whether the presence of one or more of these species could be detected by the ability of the plaque to directly hydrolyze BANA. Subgingival plaque was removed from. one pocket per quadrant in periodontal patients. This plaque was assayed for BANA hydrolysis, microscopic and cultural counts and these findings were related to the clinical parameters. In some instances the effect of scaling and root planing alone or in conjunction with metronidazole on these parameters was assessed.

Fifty-three percent of over 400 plaque samples were either positive $(43 \%)$ or weakly positive $(10 \%)$ for the BANA reaction. Of the known BANA positive species, T. denticola (measured indirectly as a small spirochete) was detected in $93 \%$ of the BANA positive plaques. B. gingivalis and the Capnocytophaga species were detected in only $27 \%$ and $6 \%$ of the BANA positive plaques. B. forsythus was not monitored. The proportions of small spirochetes which would include $T$. denticola exhibited a highly significant correlation with the BANA response of the plaque (Table 7). A similar highly significant relationship was also observed with the proportions of intermediate and large size spirochetes, indicating that spiro- 
chetes representative of all morphotypes contributed to the ability of the plaque to hydrolyze BANA. Thus, BANA hydrolysis could be considered as a measure of the presence of spirochetes in the plaque.

The ability of the plaque to hydrolyze BANA could also be associated with periodontal morbidity, using probing depths as the indicator of morbidity. Plaques obtained from sites with probing depths of 2 or $3 \mathrm{~mm}$ had either undetectable spirochetes or low proportions of spirochetes and exhibited only $10 \%$ positive BANA reactions. Plaques obtained from sites $\geq 7 \mathrm{~mm}$ deep had $34 \%$ to $46 \%$ spirochetes and exhibited from 80 to $92 \%$ positive BANA reactions. No relationship between percentage of $B$. gingivalis or Capnocytophaga and probing depth was evident (17a).

These findings suggested that the ability of subgingival plaques to hydrolyze BANA could be used as a measure of periodontal morbidity in the patient. Seventy-one percent of the plaques removed from untreated patients were BANA positive, while only $8 \%$ of the plaques removed from treated and maintained patients seen at recall visits were BANA positive. Within each patient category the ability of the plaque to hydrolyze BANA identified those sites which had elevated levels and proportions of spirochetes. For example, among the recall patients the 8 BANA positive plaques averaged $20 \%$ spirochetes and 5 spirochetes per high power microscopic field (hpf), while the 90 BANA negative plaques averaged $6 \%$ spirochetes and one spirochete per hpf. This suggests that the BANA hydrolyzing activity of the plaque was able to identify those plaques with a high spirochetal load (infections) (17a).

Table 6. BANA activity of bacterial species found in subgingival plaque

\begin{tabular}{lll}
\hline BANA Positive & & BANA negative \\
\hline Treponema denticola & T. socranskii & B. gracilus \\
Bacteroides gingivalis & T. vincentii & B. ureolyticus \\
B. forsythus & T. pectinovorum & B. buccae \\
unspeciated Capnocytophaga & B. intermedius & Capno. sputigena \\
& B. melaninogenicus & C. gingivalis \\
& B. loeschii & C. ochracea \\
& B. endodontalis & F. nucleatum \\
& Wolinella recta & Selenomonas sputigena \\
& W. curva & Campylobacter concisus \\
\hline
\end{tabular}

Data taken from Refs. 11, 12, 25, 32 and unpublished results.

Table 7. Relationship between BANA hydrolysis and proportions of certain subgingival bacteria

\begin{tabular}{|c|c|c|c|c|c|}
\hline $\begin{array}{l}\text { BANA } \\
\text { Hydrolysis }\end{array}$ & $\begin{array}{c}\% \text { Small } \\
\text { Spirochetes }\end{array}$ & $\begin{array}{c}\% \text { Inter- } \\
\text { mediate } \\
\text { Spirochetes }\end{array}$ & $\begin{array}{c}\% \text { Large } \\
\text { Spirochetes }\end{array}$ & $\begin{array}{c}\% \text { B. } \\
\text { gingivalis }\end{array}$ & $\begin{array}{l}\% \text { Capno- } \\
\text { cytophaga }\end{array}$ \\
\hline Positive & $26 \pm 15$ & $11 \pm 8$ & $6 \pm 9$ & $2 \pm 8$ & $0.04 \pm 0.2$ \\
\hline Weakly Positive & $14 \pm 15$ & $7 \pm 8$ & $2 \pm 7$ & & \\
\hline Negative & $7 \pm 12$ & $1 \pm 3$ & $2 \pm 1$ & $0.1 \pm 0.1$ & $0.1 \pm 0.2$ \\
\hline Kruskal-Wallis & $\mathrm{p}<0.0001$ & $\mathrm{p}<0.0001$ & $\mathrm{p}<0.0001$ & NS & NS \\
\hline
\end{tabular}

Table 8. Effect of mechanical treatment plus metronidazole or placebo on the ability of subgingival plaque to hydrolyze BANA

\begin{tabular}{|c|c|c|c|c|c|}
\hline \multirow{3}{*}{$\begin{array}{l}\text { Treatment } \\
\text { Group }\end{array}$} & \multicolumn{5}{|c|}{ Half-Mouth Design } \\
\hline & \multicolumn{2}{|c|}{$\%$ BANA Positive } & \multirow{2}{*}{$\begin{array}{c}\% \\
\text { Change }\end{array}$} & \multicolumn{2}{|c|}{ Due to } \\
\hline & Before & After & & Scaling & Metro \\
\hline Placebo & $83(24)^{a}$ & 70 & 16 & & \\
\hline Placebo + Scaling & $85(23)$ & 32 & 62 & 46 & \\
\hline Metronidazole & $82(22)$ & 21 & 74 & & 58 \\
\hline Metronidazole + Scaling & $84(25)$ & 6 & 93 & $77 \mathrm{a}$ & litive \\
\hline
\end{tabular}

a) Number of samples.

We were interested in whether the BANA test could be used to monitor the plaque response to various forms of periodontal treatment. We evaluated in a double-blind half mouth study what effect mechanical debridement alone or in conjunction with one week of systemic metronidazole treatment would have upon the ability of the plaque to hydrolyze BANA. Prior to treatment about $85 \%$ of the monitored sites were BANA positive (Table 8). One week after treatment the proportions of plaques which exhibited a positive BANA reaction had decreased by $62 \%$ to $93 \%$ with the greatest reduction occurring in those sites which received both scaling and metronidazole. Concurrent measurements showed that the spirochetes decreased significantly, primarily in the patients who received metronidazole.

These findings suggest that BANA hydrolysis by subgingival plaque has the potential to be an objective indicator of periodontal disease activity and could be used in combination with clinical criteria both to initiate therapy and as a means to monitor the efficacy of treatment. However, before this is done additional information is needed concerning all sources of the BANA hydrolyzing activity of the plaque, as it is possible that when this is known, the BANA test can be made both more specific and sensitive for periodontal disease activity.

\section{Multiple Enzyme Assays}

A potential way of increasing the specificity and sensitivity of an enzymatic diagnostic test would be to increase the number of enzymes that are monitored. When subgingival plaques were removed from deep pockets in treated and untreated periodontal patients and examined for their ability to hydrolyze 8 $\beta$-naphthylamide derivatives, the ability to hydrolyze L-phenylalanine, L-leucine and L-alanine was similar to that observed with BANA (Table 9) (30). However, there was no apparent added benefit derived from the usage of these additional substrates. Thus, 83 to $90 \%$ of the plaques from the untreated patients yielded a positive reaction, whereas 29 to $42 \%$ of the plaques from the treated patients gave a positive reaction.

The collection of plaque from a single site creates a sampling problem as the clinician may not know which tooth site should be sampled. This can be addressed by the collection of multiple samples or pooled samples from several teeth. 
In either case this is not as satisfactory as having a single sample that reflects the entire mouth in the way a salivary culture for the mutans streptococci can be used to diagnose caries risk. In this regard many of these enzymes can be measured in the saliva either in the supernatant or sediment (23). Higher enzyme activities were found in the supernatants obtained from 10 periodontitis patients than were found in the supernatants obtained from 10 periodontally healthy patients for alkaline phosphatase, esterase, esterase-lipase, leucine-valine- and cystine aminopeptidases, $\beta$-glucuronidase and $\alpha$-glucosidase. No difference in trypsin-like activity was found. In addition the supernatants from the periodontitis patients showed significantly greater ability to hydrolyze 9 of over 50-naphthylamide derivatives that were evaluated (23).

These findings offer the possibility that enzyme tests of saliva may yield information concerning the periodontal status of the individual. This was further suggested by studies in which the levels of the same large panel of enzymes were compared in salivary supernatant before and after periodontal treatment in 5 adults (37). The results show a significant reduction in the levels of the trypsin-like enzyme, and also in the levels of 10 other enzyme activities, 6 of which had previously been shown to be elevated in periodontitis patients (Table 10) (23). This suggests that perhaps the periodontitis patient can be recognized by a unique pattern of salivary enzymes that have a unique specificity for arginine, glycine or phenylalanine-containing compounds. It remains to be shown whether these results can be obtained with whole saliva, thereby avoiding the centrifugation step.

\section{Acknowledgements}

This research was supported by Public Health Service Grant DE 06030 and DE

Table 9. Enzymatic activities against $\beta$-naphthylamide derivative in plaques removed from pocket depths $\geq 5 \mathrm{~mm}$

\begin{tabular}{lccc}
\hline & \multicolumn{3}{c}{$\%$ of Sites with Positive Reaction } \\
\cline { 2 - 4 } $\begin{array}{l}\text { B-naphthyl- } \\
\text { amide derivatives }\end{array}$ & $\begin{array}{c}\text { Untreated } \\
\text { Periodontitis } \\
\mathrm{n}=41\end{array}$ & $\begin{array}{c}\text { Treated Patients } \\
\text { Seen at Recall } \\
\mathrm{n}=24\end{array}$ & $\begin{array}{c}\text { Ratio } \\
\text { Untreated/Treated }\end{array}$ \\
\hline BANA & 85 & 29 & 2.9 \\
pyrrolidine & 10 & 8 & 1.3 \\
L-phenylalanine & 88 & 38 & 2.4 \\
L-leucine & 90 & 42 & 2.1 \\
L-valine & 12 & 0 & \\
L-serine & 5 & 0 & 3 \\
L-arginine & 24 & 8 & 2.5 \\
L-alanine & 83 & 33 &
\end{tabular}

Adapted from Syed et al. 1984. J. Perio. Res. 19: 618-621.

Table 10. Effect of periodontal therapya) on salivary enzymatic activity

\begin{tabular}{lcc}
\hline Enzymes & Pre-treatment & 2 wks. post-treatment ${ }^{\mathrm{a}}$ ) \\
\hline Trypsin-like & $5(3)^{\mathrm{b}} \mathrm{mM}$ & $1(2)$ \\
Cystine aminopeptidase & $10(0)$ & $4(2)$ \\
$\beta$-galactosidase & $12(4)$ & $7(4)$ \\
\hline Hydrolysis of $\beta$-napthylamide derivations & \\
Arginine & $23(5)$ & $11(5)$ \\
$\beta$-glutamine & $3(2)$ & 0 \\
Proline & $23(5)$ & $11(5)$ \\
Arginyl-arginine & $37(5)$ & $13(6)$ \\
Glycyl-arginine & $17(5)$ & $8(2)$ \\
Glycyl-phenylalamine & $10(0)$ & $6(2)$ \\
Lysyl-alanine & $20(0)$ & $12(4)$ \\
Phenylalanine-arginine & $33(5)$ & $15(9)$ \\
\hline Salivary bacteria & $3.54 \times 10^{10}$ & $6.0 \times 10^{10}$ \\
Spirochetes & $2 \%$ & $0 \%$ \\
Motile rods & $13 \%$ & $8 \%$ \\
\hline
\end{tabular}

a) 5 adults received 2 or more sessions of scaling and root planing and $1 \mathrm{~g} /$ day of TetracyclineHCL for 14 days. Adapted from Zambon et al. 1985. J. Perio. Res. 20: 652-659.

b) Standard deviation in parentheses.
02731 from the National Institute of Dental Research. Carol Gerlach assisted in the preparation of this manuscript.

\section{References}

1. Bratthall D. Demonstration of five serological groups of streptococcal strains resembling Streptococcus mutans. Odont Rev 1970; 21: 143-152.

2. Ciardi J. Purification and properties of glucosyltransferases of Streptococcus mutans: a review. In: Doyle RJ, Ciardi JE, eds. Glucosyltransferases, glucans, sucrose and dental caries. Spec. Suppl. to: Chemical Senses. IRL Washington DC, 1983: 1-64.

3. Cimasoni G. Crevicular Fluid Updated. Monographs in Oral Sciences. Myers HM, ed. Karger, Basel. 1983; 12: 152p.

4. Coykendall AL. Proposal to elevate the subspecies of Streptococcus mutans to species status, based on their molecular composition. Int J Syst Bacteriol 1977; 27: 26-30.

5. Gold OC, Jordan HV, van Houte J. A selective medium for Streptococcus mutans. Archs Oral Biol 1973; 18: 1356-1364.

6. Hofstad T. Evaluation of the API-Zym System for identification of Bacteroides and Fusobacterium species. Med Microbiol Immunol 1980; 168: 173-177.

7. Keyes PH, Rams TE. A rationale for the management of periodontal diseases: rapid identification of microbial "therapeutic targets" with phase-contrast microscopy. J Am Dent Assoc 1983; 106: 803-812.

8. Kohler B, Andreen I, Jonsson B, Hultquist E. Effect of caries preventive measures on Streptococcus mutans and lactobacilli in selected mothers. Scand $J$ Dent Res 1982; 90: 102-108.

9. Krasse B. Caries Risk. A Practical Guide for Assessment and Control. Quintessence Publ Co Chicago 1985; 113pp.

10. Larmas M. A new dip-slide method for the counting of salivary lactobacilli. Proc Finn Dent Soc 1975; 71: 31-35.

11. Laughon BE, Syed SA, Loesche WJ. Rapid identification of Bacteroides gingivalis. J Clin Microbiol 1982; 15: 345-346.

12. Laughon BE, Syed SA, Loesche WJ. API-ZYM system for identification of Bacteroides sp., Capnocytophaga sp. and spirochetes of oral origin. J Clin Microbiol 1982; 15: 97-102.

13. Listgarten MA, Hellden L. Relative distribution of bacteria at clinically healthy and periodontally diseased sites in humans. J Clin Periodontol 1978; 5: $115-132$.

14. Loesche WJ. Chemotherapy of dental plaque infections. Oral Sci Rev 1976; 9: 63-107.

15. Loesche WJ. Dental Caries: A Treatable 
Infection. Charles C. Thomas, Publisher. Springfield, IL, 1982; 558 pp.

16. Loesche WJ, Bhat B. Evaluation of diagnostic broths for Streptococcus mutans. In: Stiles HM, Loesche WJ, O'Brien TC, eds. Proc Microbial Aspects of Dental Caries. Sp Suppl Microbiol Abstr. 1976; 291-301.

17. Loesche WJ, Laughon B. Role of spirochetes in periodontal disease. In HostParasite Interactions in Periodontal Disease. Genco RJ, Mergenhagen SE, eds. Amer Soc for Microbiol. Washington DC. 1982 ; pp. $62-75$.

17a Loesche WJ, Syed SS, Stoll J. Trypsinlike activity in subgingival plaque: A diagostic marker for spirochetes and periodontal disease? J Periodontol 1987; 58 (in press)

18. Loesche WJ, Syed SA, Morrison EC, Kerry GA, Higgins T, Stoll J. Metronidazole in periodontitis. I Clinical and bacteriological results after 15 to 30 weeks. $J$ Periodontol 1984; 55: 325-335.

19. Loesche WJ, Syed SA, Schmidt E, Morrison EC. Bacterial profiles of subgingival plaques in periodontitis. $J$ Periodontol 1985; 56: 447-456.

20. Matsukubo T, Saito H, Ohta K, Maki Y, Sazuka JI, Takaesu Y, Takazoe I, Asami K. A practical method for differentiating the salivary levels of Streptococcus mutans using a stabilized selective broth. Bull Tokyo Dent Coll 1983; 24: 195-202.

21. Moore WEC, Holdeman LV, Smibert RM, Hash DE, Burmeister JA, Ranney RR. Bacteriology of severe periodontitis in young adult humans. Infect Immun 1982; 38: 1137-1145.

22. Moore WEC, Ranney RR, Holderman LV. Subgingival microflora in periodontal disease: Cultural studies in: HostParasite Interactions in Periodontal Diseases. Amer Soc for Microbiol. Washington DC. 1982; pp. 13-26.

23. Nakamura M, Slots J. Salivary enzymes. Origin and relationship to periodontal disease. $J$ Periodont Res 1983; 18: 559-569.

24. Shklair IL, Keene HJ. Biochemical characterization and distribution of Streptococcus mutans in three diverse populations, in: Stiles HM, Loesche WJ, O'Brien TC, eds. Proceedings: Microbial Aspects of Dental Caries (spec suppl to Microbiol Abstr vol 3). Information Retrieval Inc. Washington, D.C. 1976; 201-210.

25. Slots J. Enzymatic characterization of some oral and nonoral gram-negative bacteria with the API-zym system. $J$ Clin Microbiol 1981; 14: 288-294.

26. Slots J, Genco RJ. Black-pigmented Bacteroides species, Capnocytophaga species, and Actinobacillus actinomycetemcomitans in human periodontal disease: virulence factors in colonization, survival and tissue destruction. J Dent Res 1984; 63: $412-421$.

27. Slots J, Hafstrom C, Rosling B, Dahlen G. Detection of Actinobacillus actinomycetemcomitans and Bacteroides gingivalis in subgingival smears by the indirect fluorescent-antibody technique. $J$ Periodont Res 1985; 20: 613-620.

28. Socransky SS, Tanner ACR, Haffajee A, Hillman JD, Goodson JD. Present status of studies on the microbial etiology of periodontal diseases. Chapter in Host Parasite Interactions in Periodontal Disease. Genco RJ, Mergenhagen SE, eds. Am Soc Microbiol 1982; 1-12.

29. Svanberg M, Loesche WJ. Salivary concentration of Streptococcus mutans and Streptococcus sanguis and the colonization of artificial fissures in humans by these organisms. Archs Oral Biol 1977; 22: $441-447$

30. Syed SA, Gusberti FA, Loesche WJ, Lang NP. Diagnostic potential of chromogenic substrates for rapid detection of bacterial enzymatic activity in health and disease associated periodontal plaques. $J$ Periodont Res 1984; 19: 618-621.
31. Tanner AC, Socransky SS, Goodson JM. Microbiota of periodontal pockets losing crestal alveolar bone. $J$ Periodont Res 1984; 19: 279-291.

32. Tanner ACR, Strzempko MN, Belsky CA, McKinley GA. API-Zym and APIANADENT reactions of fastidious gram negative species. J Clin Microbiol 1985; 22: 333-335.

33. Tanner AC, Haffer C, Bratthall GT, Visconti RA, Socransky SS. A study of the bacteria associated with advancing periodontitis in man. J Clin Periodontol 1979; 6: 278-292.

34. van Houte J, Green DB. Relationship between the concentration of bacteria in saliva and the colonization of teeth in humans. Infect Immun 1974; 9: 624-630.

35. Wolff LF, Bakdash MB, Bandt CL. Microbial interpretation of plaque relative to the diagnosis and treatment of periodontal disease. $J$ Periodontol 1985; 56: 281-284.

36. Zambon JJ. Actinobacillus actinomycetemcomitans in human periodontal disease. J Clin Periodontol 1985; 12: 1-20.

37. Zambon JJ, Nakamura M, Slots J. Effect of periodontal therapy on salivary enzymatic activity. $J$ Periodont Res 1985; 20: 652-659.

38. Zambon JJ, Reynolds HS, Chen P, Genco RJ. Rapid identification of periodontal pathogens in subgingival dental plaque. Comparison of indirect immunofluorescence microscopy with bacterial culture for detection of Bacteroides gingivalis. $J$ Periodontol 1985; 56 (11 Suppl.): $32-40$

39. Zickert I, Emilson CG, Krasse B. Effect of caries preventive measures in children highly infected with S. mutans. Archs Oral Biol 1982; 27: 861-868.

40. Zickert I, Emilson CG, Krasse B. Correlation of level and duration of Streptococcus mutans infection with incidence of dental caries. Infect Immun 1983; 39: 982-985. 
This document is a scanned copy of a printed document. No warranty is given about the accuracy of the copy. Users should refer to the original published version of the material. 